\title{
Influence of substrate base on sports field covered with bermuda grass ${ }^{(1)}$
}

\author{
CAROLINE DE MOURA D'ANDRÉA MATEUS(2), MAURÍCIO ROBERTO DE OLIVEIRA ${ }^{(3)}$, \\ CAMILA PAULA ROSSETTO PESCATORI JACON ${ }^{(2)}$, ARMANDO REIS TAVARES ${ }^{(4)}$,MARIA MÁRCIA PEREIRA \\ SARTORI'), DIRCEU MAXIMINO FERNANDES ${ }^{(2)}$, ROBERTO LYRA VILLAS BÔAS ${ }^{(2)}$
}

\begin{abstract}
The sports field consists of three layers (sub-base, base (substrate) and grass). The base is responsible for the radicular development of the grass, directly influencing the characteristics that provide quality, water drainage and lawn durability and allows athlete performance. The construction of sports field base generally follows USGA (United States Golf Association) recommendations for golf course greens. Sand is the main component based on its high capacity for drainage. This study aimed to define the best composition of the base for sports fields covered with Bermuda grass. The following treatments were evaluated: T1: sand; T2: sand $(80 \%)+$ peat $(20 \%)$; T3: sand $(90 \%)+$ clay soil $(10 \%)$; T4: sand $(70 \%)+$ sandy soil $(30 \%)$ during 12 months. The experimental design consisted of a randomized block design, with a 4 x 12 factorial design (treatments $\mathrm{x}$ months), with 3 replicates and each plot measuring $3 \times 4 \mathrm{~m}$. During one full year, the following parameters were evaluated: surface traction of the turf, mechanical resistance of the base to penetration, humidity of the base, concentration of nutrients in grass clippings, and chemical analysis of the base. The tallest grass occurred in substrate of sand mixed with peat. This mixture also promoted the highest $\mathrm{N}$ and $\mathrm{P}$ levels in the leaves of Bermuda grass. Playability of the sports field, as determined by mechanical strength and surface traction, was unaffected by the type of substrate. The presence of peat, sand and clay soil mixed with sand promoted greater water retention at the base.
\end{abstract}

Keywords: Tifton 419, athletic fields, sand, peat, gameplay.

\section{RESUMO}

Composição do substrato na qualidade de gramado esportivo de grama bermuda

O gramado esportivo é formado por três camadas (sub-base, base (substrato) e grama), sendo a base responsável pelo desenvolvimento radicular da grama, influenciando diretamente as características que proporcionam qualidade, drenagem de água e durabilidade ao gramado e permitem o desempenho do atleta. A construção da base dos gramados esportivos é baseada nas recomendações da USGA (United States Golf Association) para greens de campo de golfe, tendo como principal componente a areia, devido à sua alta capacidade de drenagem. A matéria orgânica também precisa estar presente para suprir as demais necessidades físicas e químicas da grama. Objetivou-se com este trabalho definir a melhor composição da base para gramados esportivos de grama bermuda. Foram avaliados os seguintes tratamentos: T1: areia; T2: areia $(80 \%)+$ turfa $(20 \%)$; T3: areia $(90 \%)+$ solo argiloso $(10 \%)$; T4: areia $(70 \%)+$ solo arenoso $(30 \%)$, ao longo de 12 meses. O delineamento experimental utilizado foi em blocos casualizados, composto por fatorial 4 x 12 (tratamentos x meses), com 3 repetições, tendo cada parcela a dimensão de 3 x $4 \mathrm{~m}$. Durante um ano foram realizadas as seguintes avaliações: tração superficial do gramado, resistência mecânica da base à penetração, umidade da base, concentração de nutrientes na lâmina foliar da grama bermuda e análise química da base. O maior crescimento do gramado ocorreu na base (substrato) onde a areia foi misturada com a turfa. Esta mistura promoveu, também, os mais elevados teores de $\mathrm{N}$ e P nas folhas da grama bermuda. A resistência mecânica e tração superficial, características que influenciam a jogabilidade de um gramado de campo de futebol não foram afetadas pelas diferentes misturas na composição da base. A presença de turfa, solo arenoso e argiloso misturados à areia promoveram maior retenção de água na base.

Palavras-chave: Tifton 419, campo esportivo, areia, turfa, jogabilidade.

\section{INTRODUCTION}

Sports field grass differs from ornamental grass owing to its characteristic tolerance to wear and tear, as well as normal field use. Bermuda grass (Cynodon dactylon x $C$. transvalensis) is the most used grass for sporting purposes in Brazil based on its superior regenerative ability in areas damaged by excessive foot traffic. Bermuda grass is a highly variable, sod forming perennial that spreads by stolons, rhizomes and seed; grows best under extended periods of high temperatures, mild winters and moderate to high rainfall in general, are drought tolerant, but do not tolerate poorly drained sites as compacted sites and heavy clay soils (DUBLE, 2001).

DOI http://dx.doi.org/10.14295/oh.v23i3.1104

${ }^{(1)}$ Received in 10/07/2017 and accepted in 26/09/2017

(2)Universidade Estadual Paulista “Júlio de Mesquita Filho" (UNESP), Faculdade de Ciências Agronômicas (FCA), Departamento de Solos e Recursos Ambientais, Botucatu-SP, Brazil. *Corresponding author: caroline@fca.unesp.br

${ }^{(3)}$ Fertigrama, Botucatu-SP, Brazil.

(4)Instituto de Botânica, São Paulo-SP, Brazil.

Licensed by CC BY 4.0 
Sports field turf is composed of sub-base, base (substrate), and grass, or vegetation cover. These components, originally adopted for golfing greens in the United States, have been used in other sports fields, among them soccer fields (NIRSA, 2009). The base of sports fields should be composed of sand of different granulometries, allowing for efficient drainage (USGA, 1993). The physical characteristics of the base are extremely important, mainly its density and porosity, which directly influence root development and the availability of air and water to the plant (KÄMPF, 2001; SANTOS et al., 2002; FERRAZ and CENTURION, 2005). These characteristics are directly affected by compaction, which results in compression with correspondingly higher density and mechanical resistance, while, at the same time, reducing soil particle porosity and thus limiting the infiltration and redistribution of water, making gas exchange difficult. These characteristics will, in turn, influence the chemical characteristics of the base and interfere with the movement of nutrients, thus reducing their use efficiency by plants (SANTOS et al., 2002; MORAES et al., 2008). A compacted base will also hinder the practice of sports, leading to increased risk of knee and ankle injury (FIFA, 2010). Agronomic techniques, such as leveling and drainage of the area, irrigation systems, and control of the physical and chemical characteristics of the soil and/or substrate are used to enhance the quality of sports field turf (KUHN and HAYDEN, 2012).

This study aimed to determine the best substrate composition of the base for natural fields covered with Bermuda grass.

\section{MATERIAL AND METHODS}

In order to carry out the experiment, an appropriate area at the Faculdade de Ciências Agronômicas, Universidade Estadual Paulista "Julio de Mesquita Filho" (FCA/ UNESP), Botucatu, São Paulo State, Brazil (22 $51^{\circ}$ 'S and $48^{\circ} 26^{\prime} \mathrm{W}$, average altitude of $786 \mathrm{~m}$, average temperature during experimentation of $20.7^{\circ} \mathrm{C}$ and total precipitation of $800 \mathrm{~mm}$ ), was chosen.

The experimental design was a completely randomized block with 4 treatments with a factorial $4 \times 12$ (treatments $\mathrm{x}$ months), with 3 replicates, each plot having a dimension of $3 \times 4 \mathrm{~m}$. The experiment was carried out for 12 months. Four substrate compositions were studied to formulate the base of the sports field: T1 - sand, T2 - 80\% sand $+20 \%$ peat moss ( $\mathrm{pH}-6.0$, electrical conductivity - $4 \mathrm{dS} \mathrm{m} \mathrm{m}^{-1}, 103 \%$ of water retention capacity (WRC), and cation-exchange capacity (CEC) - $800 \mathrm{mmol}_{\mathrm{c}} \mathrm{dm}^{3}$ ), T3 - 90\% sand $+10 \%$ clay soil (alic purple latosol) and T4 - 70\% sand $+30 \%$ sandy soil (dystrophic red latosol). The sand was selected from samples taken from companies that mine river sand near the Botucatu region of southeastern Brazil at the confluence of the Piracicaba, Tietê and Paranapanema Rivers. The samples were analyzed in the Soil Physics Laboratory of the Department of Soils and Environmental Resources of FCA/UNESP. A sieve analysis test was used to determine sand sizes. The chosen experimental sample (Porto de Areia Santa Isabel, Igaraçu do Tietê, SP) was close to the USGA standard for sand size and is presented in Table 1. Soils were classified according to the system established by The Brazilian Agricultural Research Corporation (EMBRAPA, 2013).

Table 1. Granulometric distribution of sand to base composition as recommended by the United States Golf Association (USGA).

\begin{tabular}{|c|c|c|}
\hline Caracterization & Granulometry $(\mathbf{m m})$ & Recomendation (\%) \\
\hline Very coarse sand & $1.0-2.0$ & $\leq 10$ \\
\hline Coarse sand & $0.5-1.0$ & $\geq 60$ \\
\hline Medium sand & $0.25-0.50$ & $\leq 20$ \\
\hline Fine sand & $0.15-0.25$ & $\leq 5$ \\
\hline Very fine sand* & $0.05-0.15$ & $\leq 5$ \\
\hline Silt* & $0.002-0.05$ & $\leq 5$ \\
\hline Clay* & $<0.002$ & \\
\hline
\end{tabular}

* These three classes can not be higher than $10 \%$.

The experimental area was designed as a regular sports field composed of the three necessary layers: sub-base, base, and turf. The sub-base was composed of soil classified as medium-textured red latosol (EMBRAPA, 2013), and for drainage, two channels $20 \mathrm{~cm}$ deep and $20 \mathrm{~cm}$ wide were excavated to place tubing measuring $10 \mathrm{~cm}$ in diameter in each plot. The entire area was later covered with geotextile blanket and sand. A sprinkler irrigation system, using six retractable sprinklers, was installed between the drainage system and the base (flow from 0.17 to $1.85 \mathrm{~m}^{3} \mathrm{~h}^{-1}$ and reaching 7.5 to $14 \mathrm{~m}$ ).

The chemical characteristics of samples from each base used as treatment were determined and shown in Table 2. Based on these results and aiming to increase substrate saturation by $65 \%, 18 \mathrm{~g} \mathrm{~m}^{-2}$ of $\mathrm{P}_{2} \mathrm{O}_{5}$ were applied, except for T2, owing to the already high levels of $\mathrm{P}_{2} \mathrm{O}_{5}$. 
Table 2. Chemical composition of the substrates composing the base.

\begin{tabular}{|c|c|c|c|c|c|c|c|c|c|c|}
\hline & pH & O.M. & $\mathbf{P}_{\text {resine }}$ & $\mathbf{H}+\mathbf{A l}$ & $\mathbf{K}$ & $\mathrm{Ca}$ & Mg & SB & CEC & V\% \\
\hline & $\mathrm{CaCl}_{2}$ & $\mathrm{~g} \mathrm{dm}^{-3}$ & $\mathrm{mg} \mathrm{dm} \mathrm{m}^{-3}$ & \multicolumn{6}{|c|}{$\mathrm{mmol}_{\mathrm{c}} \mathrm{dm}^{-3}$} & \\
\hline T1: sand & 5.0 & 1 & 7 & 8 & 0.5 & 4 & 2 & 6 & 15 & 41 \\
\hline $\mathrm{T} 2$ : sand + peat & 4.9 & 24 & 36 & 26 & 1.6 & 37 & 9 & 47 & 73 & 65 \\
\hline T3: sand + clay & 4.7 & 1 & 5 & 10 & 0.5 & 4 & 2 & 6 & 16 & 39 \\
\hline \multirow{3}{*}{ T4: sand + sandy soil } & 4.1 & 20 & 3 & 69 & 0.5 & 4 & 3 & 7 & 76 & 10 \\
\hline & $\mathrm{Cu}$ & $\mathrm{Fe}$ & Zn & Mn & B & & & & & \\
\hline & \multicolumn{5}{|c|}{$\mathrm{mg} \mathrm{dm}{ }^{-3}$} & & & & & \\
\hline T1: sand & 0.1 & 30 & 0.5 & 2.5 & 0.28 & & & & & \\
\hline $\mathrm{T} 2$ : sand + peat & 0.2 & 583 & 1.3 & 7.9 & 0.28 & & & & & \\
\hline T3: sand + clay & 9.2 & 29 & 0.2 & 2.4 & 0.28 & & & & & \\
\hline T4: sand + sandy soil & 0.1 & 41 & 0.7 & 3.1 & 0.19 & & & & & \\
\hline
\end{tabular}

Experimental grass was an interspecific hybrid of Bermuda grass (Cynodon dactylon $\mathrm{x}$ Cynodon transvaalensis) called Tifton 419. Before planting, the grass was washed to remove adherent soil on roots and rhizomes. For better attachment of the sods, a compaction roller was used. Fifteen days after planting, the turf was covered with sand for uniformity and to fill the voids. A border $2 \mathrm{~m}$ wide was built at the side of the experiment using the same grass as that of the experimental area.

The experimental area was irrigated daily, and the turf was pruned to a height of $25 \mathrm{~mm}$ to encourage regrowth. Sand was applied to maintain a level area, and manual weed control herbicides were applied during the period of establishment and formation of the experiment.

Liming was performed in all treatments before planting the grass with the aim of raising base saturation to $65 \%$. Initial fertilization utilized $5 \mathrm{~g} \mathrm{~N} \mathrm{~m}^{-2}$ (ammonium nitrate), $2 \mathrm{~g} \mathrm{P}_{2} \mathrm{O}_{5} \mathrm{~m}^{-2}$ (single superphosphate) and $5 \mathrm{~g} \mathrm{~K}_{2} \mathrm{O} \mathrm{m}^{-2}$ (potassium chloride) and was carried out 30 days after planting the sods. Fertilization was divided into 4 weekly applications. After the initial fertilization, $50 \mathrm{~g} \mathrm{~m}^{-2}$ of a commercial fertilizer $\left(13 \% \mathrm{~N}, 5 \% \mathrm{P}_{2} \mathrm{O}_{5}, 13 \% \mathrm{~K}_{2} \mathrm{O}, 1 \% \mathrm{Ca}\right.$, $1 \% \mathrm{Mg}, 5 \% \mathrm{~S}, 0.04 \% \mathrm{~B}, 0.05 \% \mathrm{Cu}, 0.2 \% \mathrm{Fe}, 0.08 \% \mathrm{Mn}$, $0.005 \% \mathrm{MO}$ and $0.15 \% \mathrm{Zn}$ ) was alternated every 15 days with $100 \mathrm{~g} \mathrm{~m}^{-2}$ of a 20-5-20 commercial fertilizer.

After one year of experimentation, the following evaluations were carried out during the formation and stabilization of the turf. 1) Chemical analysis of the base substrate $(\mathrm{pH}$, organic matter, cation exchange capacity and base saturation) was performed each month from a sample composed of 5 subsamples of each plot ( 0 to $10 \mathrm{~cm}$ deep), following Raij et al. (2001). 2) Macronutrient contents of grass (N, P and K) were determined in a composite sample of grass clippings obtained in the total area of each plot, according to the modified methodology of Malavolta et al. (1997). The preparation of the samples was performed according to Plank and Carrow (2003). The cut for removal of the grass clippings for use in all evaluations was performed one week after the previous cut of $25 \mathrm{~mm}$. 3) Base moisture was determined monthly at 3 points per plot, using Delta-T equipment (Model ML 2X Theta probe, Delta-T Devices Ltd.). The equipment has 4 metal rods that generate a signal of $100 \mathrm{MHz}$ and extend to the interior of the ground. 4) The mechanical resistance of the base to penetration was evaluated monthly with an electronic penetrometer (PLG 5300 Solotrack Falker), having a constant velocity of $10 \mathrm{~m} \mathrm{~s}^{-1}$ and allowing measurements every centimeter (average of $20 \mathrm{~cm}$ ), and was realized in 3 points per plot. 5) Turf surface traction measurement (Nm) was evaluated monthly (3 points per plot) with a Rotational Resistance Tester (Deltec Metaal $\left.{ }^{\circledR}\right)$.

The data were submitted to the test of normality, heterogeneity and analysis of variance (ANOVA), and means were compared using the Tukey test at $5 \%$ probability with the Minitab 13.0 software (MINITAB, 2000).

\section{RESULTS AND DISCUSSION}

The base T2 (sand + peat) had the lowest $\mathrm{pH}$ values (Table 3). Peat normally has low $\mathrm{pH}$ owing to the cellular sap of the plants that originate them by acidic reactions (LAMIN et al., 2001). The average $\mathrm{pH}$ of peat in the experiment was 4.5 . 
Table 3. Base $\mathrm{pH}$ of treatments during experimentation $(n=3)$.

\begin{tabular}{|c|c|c|c|c|c|c|c|c|c|c|c|c|c|}
\hline \multirow{3}{*}{ Treatments } & \multicolumn{12}{|c|}{ Base pH } & \multirow{3}{*}{ Average } \\
\hline & Jul & Aug & Sep & Oct & Nov & Dec & Jan & Feb & Mar & Apr & May & Jun & \\
\hline & 1 & 2 & 3 & 4 & 5 & 6 & 7 & 8 & 9 & 10 & 11 & 12 & \\
\hline $\mathrm{T} 1$ & 4.8 & 5.2 & 4.9 & 5.2 & 4.9 & 4.5 & 5.0 & 5.1 & 4.9 & 4.7 & 4.8 & 4.6 & $4.9 \mathrm{~A}$ \\
\hline T2 & 4.3 & 4.5 & 4.3 & 4.3 & 4.0 & 3.7 & 4.2 & 4.1 & 4.3 & 3.9 & 4.0 & 3.8 & $4.1 \mathrm{D}$ \\
\hline T3 & 4.5 & 5.0 & 4.7 & 4.9 & 4.5 & 4.3 & 4.6 & 4.5 & 4.6 & 4.5 & 4.8 & 4.4 & $4.6 \mathrm{~B}$ \\
\hline T4 & 4.3 & 4.8 & 4.3 & 4.6 & 4.4 & 4.2 & 4.6 & 4.5 & 4.5 & 4.3 & 4.7 & 4.3 & $4.5 \mathrm{C}$ \\
\hline \multirow[t]{2}{*}{ Average } & $4.5 \mathrm{~cd}$ & $4.9 \mathrm{a}$ & $4.5 \mathrm{bcd}$ & $4.8 \mathrm{ab}$ & $4.5 \mathrm{~cd}$ & $4.2 \mathrm{e}$ & $4.6 \mathrm{abc}$ & $4.6 \mathrm{bc}$ & $4.6 \mathrm{bc}$ & $4.4 \mathrm{cde}$ & $4.6 \mathrm{bc}$ & $4.3 \mathrm{de}$ & \\
\hline & \multicolumn{13}{|c|}{ 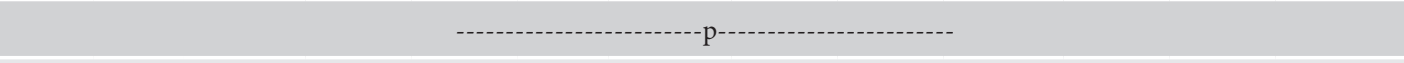 } \\
\hline Months (M) & \multicolumn{13}{|c|}{0.0001} \\
\hline Treatments (T) & \multicolumn{13}{|c|}{0.0001} \\
\hline $\mathrm{MxT}$ & \multicolumn{13}{|c|}{0.811} \\
\hline C.V. (\%) & \multicolumn{13}{|c|}{22.77} \\
\hline
\end{tabular}

T1: Sand (100\%); T2: Sand (20\%) + Peat (80\%); T3: Sand (90\%) + Clay soil (10\%); T4: Sand (70\%) + Sand soil (30\%).

Averages followed by uppercase letters in the column and lower case letters in the row do not differ by Tukey's test.

Base T2 also had high values of organic matter (Table 4) that persisted during the entire experimental period. Peat is a chemically complex material composed of four main groups: bitumens (fatty acids, waxes and steroids), humic substances (humic and fulvic acids and humins), carbohydrates (mainly cellulose and proteins) and lignins (polyphenolic substances, e.g., humic acids), with lignin and cellulose as major constituents (FUCHSMAN, 1974).

Table 4. Organic matter of the base during experimentation $(n=3)$.

\begin{tabular}{|c|c|c|c|c|c|c|c|c|c|c|c|c|c|}
\hline \multirow{3}{*}{ Treatments } & \multicolumn{12}{|c|}{ Organic Matter in the Base } & \multirow[b]{2}{*}{ Average } \\
\hline & Jul & Aug & Sep & Oct & Nov & Dec & Jan & Feb & Mar & Apr & May & Jun & \\
\hline & 1 & 2 & 3 & 4 & 5 & 6 & 7 & 8 & 9 & 10 & 11 & 12 & \\
\hline \multicolumn{14}{|c|}{$\mathrm{g} \mathrm{dm}^{-3}$} \\
\hline T1 & 4 & 4 & 5 & 7 & 4 & 5 & 6 & 7 & 8 & 6 & 6 & 7 & $6 \mathrm{~B}$ \\
\hline $\mathbf{T 2}$ & 31 & 43 & 30 & 35 & 40 & 34 & 33 & 35 & 37 & 35 & 31 & 39 & $35 \mathrm{~A}$ \\
\hline T3 & 4 & 5 & 5 & 8 & 6 & 6 & 7 & 7 & 8 & 8 & 6 & 7 & $6 \mathrm{~B}$ \\
\hline T4 & 6 & 6 & 8 & 8 & 6 & 8 & 8 & 8 & 8 & 8 & 8 & 7 & $7 \mathrm{~B}$ \\
\hline \multirow{2}{*}{ Average } & 11 & 15 & 12 & 15 & 14 & 13 & 14 & 14 & 15 & 14 & 13 & 15 & \\
\hline & \multicolumn{13}{|c|}{---------------------------p-------------------------- } \\
\hline Months (M) & & & & & & & 0.025 & & & & & & \\
\hline $\begin{array}{l}\text { Treatments } \\
\text { (T) }\end{array}$ & & & & & & & 0.0001 & & & & & & \\
\hline $\mathrm{M} \times \mathrm{T}$ & & & & & & & 0.038 & & & & & & \\
\hline C.V. (\%) & \multicolumn{13}{|c|}{4.90} \\
\hline
\end{tabular}

T1: Sand (100\%); T2: Sand (20\%) + Peat (80\%); T3: Sand (90\%) + Clay soil (10\%); T4: Sand (70\%) + Sand soil (30\%).

Averages followed by uppercase letters in the column and lower case letters in the row do not differ by Tukey's test.

Base T1 (sand) showed the lowest CEC (cation exchange capacity) values, and base $\mathrm{T} 2$ (peat + sand) the higher CEC values (Figure 1). In addition to its ability to absorb water, peat can increase CEC in soils. The two main properties of peat are its cation-exchange capacity, or CEC, and buffering power since organic colloids have specific exposure to areas two to ten times greater than mineral soil colloids (LAMIM et al., 2001). Base T2 (sand + peat) could retain cations and, thus, reduce the leaching of basic cations, such as calcium, magnesium, and potassium, but retain other cations, such as ammonium, owing to the physicochemical properties of peat.

The desired basal saturation value was reached only on treatment T1 (pure sand) after several months. All other treatments had values lower than 65\% (Figure 2). Part of the nitrogen from the fertilizer used for turf maintenance had nitric acid origin, and after absorbing nitrate, plants generate hydroxyls. As a result of sand's low buffering power, even a small supply of hydroxyl was sufficient to maintain base saturation and the higher $\mathrm{pH}$ of $\mathrm{T} 1$. 
The highest dry mass production occurred with peat treatment (T2), and it was significantly higher than that of other treatments (Table 5). The higher water retention capacity and availability of nutrients to the plants by peat were the main reasons for high growth of the grass and, consequently, the dry mass.

Table 5. Dry mass of grass clippings during experimentation $(n=3)$.

\begin{tabular}{|c|c|c|c|c|c|c|c|c|c|c|c|c|c|}
\hline \multirow{3}{*}{ Treatments } & \multicolumn{12}{|c|}{ Dry Mass } & \multirow{3}{*}{ Average } \\
\hline & Jul & Aug & Sep & Oct & Nov & Dec & Jan & Feb & Mar & Apr & May & Jun & \\
\hline & 1 & 2 & 3 & 4 & 5 & 6 & 7 & 8 & 9 & 10 & 11 & 12 & \\
\hline & \multicolumn{12}{|c|}{ G } & \\
\hline T1 & 3.1 & 55.7 & 222.5 & 115.4 & 39.3 & 974.8 & 1035.5 & 1336.7 & 1332.2 & 1210.5 & 1077.8 & 1072.7 & 706.3B \\
\hline $\mathbf{T} 2$ & 6.0 & 53.7 & 532.7 & 249.2 & 40.7 & 1172.6 & 1749.2 & 1927.9 & 1901.6 & 1887.4 & 1695.0 & 1957.6 & $1097.8 \mathrm{~A}$ \\
\hline T3 & 4.4 & 40.3 & 471.3 & 231.7 & 41.3 & 1027.2 & 1110.1 & 1440.8 & 1133.1 & 1544.3 & 1374.1 & 1250.6 & $805.8 \mathrm{~B}$ \\
\hline T4 & 2.6 & 42.3 & 390.7 & 178.1 & 40.7 & 1442.1 & 922.3 & 1072.0 & 1092.3 & 1237.7 & 1098.4 & 889.9 & $700.8 \mathrm{~B}$ \\
\hline \multirow[t]{2}{*}{ Average } & $4.0 \mathrm{c}$ & $48.0 \mathrm{bc}$ & $404.3 b$ & $193.6 \mathrm{bc}$ & $40.5 b c$ & $1154.2 \mathrm{a}$ & $1204.2 \mathrm{a}$ & $1444.4 \mathrm{a}$ & $1364.8 \mathrm{a}$ & $1470.0 \mathrm{a}$ & $1311.3 \mathrm{a}$ & $1292.7 \mathrm{a}$ & \\
\hline & \multicolumn{13}{|c|}{-- p - } \\
\hline Months (M) & \multicolumn{13}{|c|}{0.0001} \\
\hline $\begin{array}{l}\text { Treatments } \\
\text { (T) }\end{array}$ & \multicolumn{13}{|c|}{0.0001} \\
\hline $\mathrm{MxT}$ & \multicolumn{13}{|c|}{0.073} \\
\hline C.V. $(\%)$ & \multicolumn{13}{|c|}{2.85} \\
\hline
\end{tabular}

T1: Sand (100\%); T2: Sand (20\%) + Peat (80\%); T3: Sand (90\%) + Clay soil (10\%); T4: Sand (70\%) + Sand soil (30\%).

Averages followed by uppercase letters in the column and lower case letters in the row do not differ by Tukey's test.

After cutting, nitrogen $(\mathrm{N})$ content in the grass clippings over the 12 months of experimentation ranged from 34 to $38 \mathrm{~g} \mathrm{~kg}^{-1}$ (Table 6). During the experimental period, variations in $\mathrm{N}$ concentration in the grass clippings were observed, which could be attributed to fertilization (monthly fertilization and harvesting) and/or precipitation and grass interaction with the base. It should be noted that some $\mathrm{N}$ was exported when the turf was cut and grass clippings subsequently collected and removed from the study area. In addition, climatic conditions, such as high temperature and radiation, promote plant transpiration, which favors nitric $\mathrm{N}$ uptake via mass flow. The highest $\mathrm{N}$ concentrations of grass clippings occurred at month 2 (51 $\left.\mathrm{g} \mathrm{kg}^{-1}\right)$, corresponding to the beginning of the experiment and formation of the experimental sports field, and the decrease is observed in months $8,9,10,11$ and 12 (February to June), when the dry mass of grass clippings was higher (Table 6). The increase of $\mathrm{N}$ levels in the grass leaves could be explained by the lower plant growth, resulting in a further increase in nutrient concentration in foliar tissue. Most $\mathrm{N}$ contents observed in grass clippings were within the range of 30 to $50 \mathrm{~g} \mathrm{~kg}^{-1}$ $\mathrm{N}$, defined as appropriate by McCarty et al. (2003), except for month 12, which had lower results. 
Table 6. Nitrogen contents in grass clippings during experimentation $(n=3)$.

\begin{tabular}{|c|c|c|c|c|c|c|c|c|c|c|c|c|c|}
\hline \multirow{3}{*}{ Treatments } & \multicolumn{12}{|c|}{ Nitrogen } & \multirow{3}{*}{ Average } \\
\hline & Jul & Aug & Sep & Oct & Nov & Dec & Jan & Feb & Mar & Apr & May & Jun & \\
\hline & 1 & 2 & 3 & 4 & 5 & 6 & 7 & 8 & 9 & 10 & 11 & 12 & \\
\hline \multicolumn{14}{|c|}{$\mathrm{g} \mathrm{kg}^{-1}$} \\
\hline T1 & 40 & 52 & 36 & 35 & 38 & 39 & 33 & 30 & 31 & 35 & 31 & 29 & $36 \mathrm{~B}$ \\
\hline T2 & 43 & 50 & 35 & 35 & 39 & 41 & 37 & 35 & 34 & 37 & 35 & 29 & $38 \mathrm{~A}$ \\
\hline T3 & 43 & 50 & 34 & 31 & 37 & 39 & 34 & 30 & 30 & 31 & 29 & 29 & $35 \mathrm{BC}$ \\
\hline T4 & 40 & 50 & 33 & 31 & 37 & 40 & 33 & 29 & 30 & 30 & 28 & 27 & $34 \mathrm{C}$ \\
\hline \multirow{2}{*}{ Average } & $42 b$ & $51 \mathrm{a}$ & $34 d$ & $33 \mathrm{def}$ & $38 \mathrm{c}$ & $40 \mathrm{bc}$ & $34 \mathrm{de}$ & $31 \mathrm{efg}$ & $31 \mathrm{efg}$ & $33 \mathrm{def}$ & $31 \mathrm{fg}$ & $29 g$ & \\
\hline & \multicolumn{13}{|c|}{ 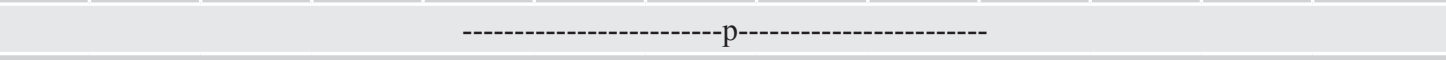 } \\
\hline Months (M) & \multicolumn{13}{|c|}{0.0001} \\
\hline $\begin{array}{l}\text { Treatments } \\
\text { (T) }\end{array}$ & \multicolumn{13}{|c|}{0.0001} \\
\hline $\mathrm{M} \times \mathrm{T}$ & \multicolumn{13}{|c|}{0.268} \\
\hline C.V. $(\%)$ & \multicolumn{13}{|c|}{16.34} \\
\hline
\end{tabular}

T1: Sand (100\%); T2: Sand (20\%) + Peat (80\%); T3: Sand (90\%) + Clay soil (10\%); T4: Sand (70\%) + Sand soil (30\%).

Averages followed by uppercase letters in the column and lower case letters in the row do not differ by Tukey's test.

The highest phosphorus (P) concentration in grass clippings occurred with treatments T1 and T2 (Table 7). This result shows that peat provided the nutrient since $\mathrm{T} 2$ did not receive inorganic phosphate fertilization at the planting, as occurred in T1. The range of $\mathrm{P}$ concentration sufficiency in Bermuda grass is 1.5 to $5.0 \mathrm{~g} \mathrm{~kg}^{-1} \mathrm{P}$ (WATSON, 1991), indicating that the grass had been adequately fertilized with phosphorus.

Table 7. Phosphorus contents in grass clippings during experimentation $(n=3)$.

\begin{tabular}{|c|c|c|c|c|c|c|c|c|c|c|c|c|c|}
\hline \multirow{3}{*}{ Treatments } & \multicolumn{12}{|c|}{ Phosphorus } & \multirow{3}{*}{ Average } \\
\hline & Jul & Aug & Sep & Oct & Nov & Dec & Jan & Feb & Mar & Apr & May & Jun & \\
\hline & 1 & 2 & 3 & 4 & 5 & 6 & 7 & 8 & 9 & 10 & 11 & 12 & \\
\hline & \multicolumn{12}{|c|}{$\mathrm{g} \mathrm{kg}^{-1}$} & \\
\hline T1 & 4.0 & 4.5 & 3.8 & 2.4 & 4.0 & 3.6 & 3.0 & 2.4 & 3.0 & 3.0 & 2.0 & 2.4 & $3.2 \mathrm{AB}$ \\
\hline $\mathbf{T} 2$ & 4.0 & 4.5 & 3.9 & 2.4 & 3.6 & 3.7 & 3.2 & 2.9 & 3.4 & 3.1 & 2.2 & 2.7 & $3.3 \mathrm{~A}$ \\
\hline T3 & 4.0 & 4.3 & 3.6 & 2.3 & 3.4 & 3.5 & 2.9 & 2.4 & 3.7 & 2.6 & 2.0 & 2.4 & $3.1 \mathrm{BC}$ \\
\hline T4 & 3.8 & 4.1 & 3.5 & 2.3 & 3.4 & 3.4 & 2.9 & 2.3 & 3.2 & 2.3 & 2.0 & 2.3 & $3.0 \mathrm{C}$ \\
\hline \multirow[t]{2}{*}{ Average } & $3.9 \mathrm{ab}$ & $4.4 \mathrm{a}$ & $3.7 \mathrm{bc}$ & $2.4 \mathrm{fg}$ & $3.6 b c$ & $3.5 b c$ & $3.0 \mathrm{de}$ & $2.5 \mathrm{f}$ & $3.3 \mathrm{~cd}$ & $2.7 \mathrm{ef}$ & $2.0 \mathrm{~g}$ & $2.5 \mathrm{fg}$ & \\
\hline & \multicolumn{13}{|c|}{-----------------------------p-------------------------- } \\
\hline Months (M) & & & & & & & 0.0001 & & & & & & \\
\hline $\begin{array}{l}\text { Treatments } \\
\text { (T) }\end{array}$ & & & & & & & 0.0001 & & & & & & \\
\hline $\mathrm{M} \times \mathrm{T}$ & & & & & & & 0.881 & & & & & & \\
\hline C.V. $(\%)$ & \multicolumn{13}{|c|}{9.66} \\
\hline
\end{tabular}

T1: Sand (100\%); T2: Sand (20\%) + Peat (80\%); T3: Sand $(90 \%)+$ Clay soil (10\%); T4: Sand (70\%) + Sand soil (30\%).

Averages followed by uppercase letters in the column and lower case letters in the row do not differ by Tukey's test.

Treatments T1, T2 and T3 showed the highest $\mathrm{K}$ concentrations in grass clippings (Table 8). The $\mathrm{K}$ levels in grass clippings in our study were within the appropriate range for $\mathrm{K}$ (10.0 to $\left.40.0 \mathrm{~g} \mathrm{~kg}^{-1}\right)$, as recommended by Jones Jr. et al. (1991). 
Table 8. Potassium contents in grass clippings during experimentation $(n=3)$.

\begin{tabular}{|c|c|c|c|c|c|c|c|c|c|c|c|c|c|}
\hline \multirow{3}{*}{ Treatments } & \multicolumn{12}{|c|}{ Potassium } & \multirow{3}{*}{ Average } \\
\hline & Jul & Aug & Sep & Oct & Nov & Dec & Jan & Feb & Mar & Apr & May & Jun & \\
\hline & 1 & 2 & 3 & 4 & 5 & 6 & 7 & 8 & 9 & 10 & 11 & 12 & \\
\hline & \multicolumn{12}{|c|}{$\mathrm{g} \mathrm{kg}^{-1}$} & \\
\hline T1 & 16 & 22 & 25 & 24 & 22 & 18 & 14 & 11 & 14 & 13 & 14 & 13 & $17 \mathrm{AB}$ \\
\hline $\mathbf{T} 2$ & 17 & 22 & 27 & 19 & 22 & 19 & 15 & 13 & 14 & 14 & 17 & 15 & $18 \mathrm{~A}$ \\
\hline T3 & 17 & 21 & 26 & 20 & 22 & 18 & 14 & 11 & 13 & 11 & 13 & 13 & $17 \mathrm{AB}$ \\
\hline T4 & 15 & 23 & 25 & 20 & 21 & 18 & 14 & 10 & 13 & 10 & 12 & 12 & $16 \mathrm{~B}$ \\
\hline \multirow[t]{2}{*}{ Average } & 16de & $22 b$ & $26 a$ & $21 b c$ & $22 b$ & $18 \mathrm{~cd}$ & $14 \mathrm{ef}$ & $11 \mathrm{~g}$ & $14 \mathrm{efg}$ & $12 \mathrm{fg}$ & $14 \mathrm{ef}$ & $13 \mathrm{fg}$ & \\
\hline & \multicolumn{13}{|c|}{---------------------------p------------------------- } \\
\hline Months (M) & \multicolumn{13}{|c|}{0.0001} \\
\hline Treatments $(\mathrm{T})$ & \multicolumn{13}{|c|}{0.010} \\
\hline $\mathrm{M} \times \mathrm{T}$ & \multicolumn{13}{|c|}{0.959} \\
\hline C.V. $(\%)$ & \multicolumn{13}{|c|}{8.36} \\
\hline
\end{tabular}

T1: Sand (100\%); T2: Sand (20\%) + Peat (80\%); T3: Sand (90\%) + Clay soil (10\%); T4: Sand (70\%) + Sand soil (30\%).

Averages followed by uppercase letters in the column and lower case letters in the row do not differ by Tukey's test.

The measurement of mechanical resistance to penetration of the base reflects the interaction between base and plant. Once established, grass develops a great amount of roots, rhizomes and stolons, which fill the porous spaces existing at the beginning of lawn formation. The mechanical resistance to penetration of the base increased by 2.5 times from the first evaluation up to month 10 , observing the average of the treatments in each month (Table 9). This result can be attributed to an accommodation of the particles of the base owing to irrigation and rainfall, as well as heavy foot traffic, especially for cut grass. Holmes and Bell (1986) used a penetrometer to measure the mechanical resistance to penetration in a soccer field and reported at least 1.4 $\mathrm{MPa}$ for areas of heavy foot traffic and at least 1.0 $\mathrm{MPa}$ for areas of moderate foot traffic. Magni et al. (2004) found great resistance to penetration on turf with sand base (2.5 MPa) when compared to turf with different drainage and non-drainage systems (1.5 MPa). Humidity is the main factor controlling the surface hardness of native soils (BAKER et al., 1991); however, turf with sand base has little variation of moisture content.

Table 9. Mechanical resistance of the base to penetration during experimentation $(n=3)$.

\begin{tabular}{|c|c|c|c|c|c|c|c|c|c|c|c|c|c|}
\hline \multirow{3}{*}{ Treatments } & \multicolumn{12}{|c|}{ Mechanical resistance of the base to penetration } & \multirow{3}{*}{ Average } \\
\hline & Jul & Aug & Sep & Oct & Nov & Dec & Jan & Feb & Mar & Apr & May & Jun & \\
\hline & 1 & 2 & 3 & 4 & 5 & 6 & 7 & 8 & 9 & 10 & 11 & 12 & \\
\hline & Mpa & & & & & & & & & & & & \\
\hline T1 & 1.01 & 1.13 & 0.97 & 1.66 & 1.72 & 2.63 & 1.29 & 2.97 & 1.55 & 1.61 & 1.30 & 2.00 & $1.65 \mathrm{~A}$ \\
\hline $\mathbf{T} 2$ & 0.87 & 1.00 & 1.46 & 1.32 & 2.11 & 2.65 & 1.45 & 2.53 & 1.77 & 2.76 & 1.53 & 2.05 & $1.79 \mathrm{~A}$ \\
\hline T3 & 1.03 & 1.07 & 1.28 & 1.71 & 1.66 & 1.42 & 1.18 & 1.72 & 1.29 & 2.63 & 1.28 & 1.72 & $1.50 \mathrm{~A}$ \\
\hline T4 & 0.82 & 0.94 & 1.44 & 1.87 & 1.79 & 1.68 & 1.18 & 1.77 & 1.28 & 2.60 & 1.31 & 1.68 & $1.53 \mathrm{~A}$ \\
\hline \multirow[t]{2}{*}{ Average } & $0.93 d$ & $1.04 \mathrm{~d}$ & $1.29 \mathrm{~cd}$ & 1.64abcd & $1.82 \mathrm{abcd}$ & $2.10 \mathrm{abc}$ & $1.28 \mathrm{~cd}$ & $2.25 \mathrm{ab}$ & $1.47 \mathrm{abcd}$ & $2.40 \mathrm{a}$ & $1.36 \mathrm{bcd}$ & $1.86 \mathrm{abcd}$ & \\
\hline & \multicolumn{12}{|c|}{---------------------------p------------------------ } & \\
\hline Months (M) & \multicolumn{13}{|c|}{0.0001} \\
\hline $\begin{array}{l}\text { Treatments } \\
\text { (T) }\end{array}$ & \multicolumn{13}{|c|}{0.254} \\
\hline $\mathrm{Mx} \mathrm{T}$ & \multicolumn{13}{|c|}{0.917} \\
\hline C.V. $(\%)$ & \multicolumn{13}{|c|}{2.36} \\
\hline
\end{tabular}

T1: Sand (100\%); T2: Sand (20\%) + Peat (80\%); T3: Sand (90\%) + Clay soil $(10 \%)$; T4: Sand $(70 \%)+$ Sand soil $(30 \%)$.

Averages followed by uppercase letters in the column and lower case letters in the row do not differ by Tukey's test.

The values of mechanical resistance to penetration were similar among the treatments, indicating that mixtures composed of sand had no influence on this parameter during the course of the experimental period. In fact, sand, as the major component of the base, is the most important factor affecting mechanical resistance to penetration of the 
turf. Lower values than the recommended would result in inferior turf stability and playability, while values higher than the recommended would result in injuries to players. Researchers from Pennsylvania State University (PSU) observed that $21 \%$ of injuries recorded for 12 high school football programs were either certainly, or potentially, associated with turf surface (MC NITT et al., 1997). Less than standard traction values cause differences in physical performance that can be easily perceived by players (SÁNCHEZ-SÁNCHEZ et al., 2014).
The composition of the base did not affect surface traction (Table 10). The recommended acceptable values for synthetic grasses (SOCCER GRASS, 2013) are between 30 and $45 \mathrm{Nm}$. The surface traction results for all treatments were well within the optimal range, except for the months where they were higher than $45 \mathrm{Nm}$, most likely a result related to variation in base moisture, considering the time of analysis and irrigation. Superior traction occurs on wet sand, which becomes firmer. This is why sports trainers dry sandbased fields before a game, thereby reducing lawn traction.

Table 10. Surface traction measurement of the turf during experimentation $(n=3)$.

\begin{tabular}{|c|c|c|c|c|c|c|c|c|c|c|c|c|c|}
\hline \multirow{3}{*}{ Treatment } & \multicolumn{12}{|c|}{ Surface traction } & \multirow{3}{*}{ Average } \\
\hline & Jul & Aug & Sep & Oct & Nov & Dec & Jan & Feb & Mar & Apr & May & Jun & \\
\hline & 1 & 2 & 3 & 4 & 5 & 6 & 7 & 8 & 9 & 10 & 11 & 12 & \\
\hline & \multicolumn{13}{|c|}{ 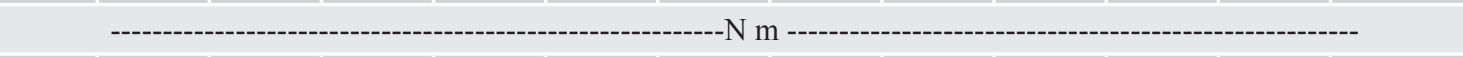 } \\
\hline T1 & 48 & 44 & 35 & 42 & 56 & 43 & 45 & 43 & 51 & 43 & 48 & 43 & $45 \mathrm{~A}$ \\
\hline $\mathbf{T 2}$ & 44 & 45 & 35 & 41 & 53 & 43 & 44 & 42 & 48 & 42 & 46 & 42 & $44 \mathrm{~A}$ \\
\hline T3 & 44 & 49 & 34 & 39 & 54 & 44 & 44 & 41 & 49 & 43 & 47 & 42 & $44 \mathrm{~A}$ \\
\hline T4 & 47 & 43 & 34 & 43 & 56 & 44 & 45 & 43 & 51 & 43 & 47 & 43 & $45 \mathrm{~A}$ \\
\hline \multirow[t]{2}{*}{ Average } & 46bcd & $45 \mathrm{bcd}$ & $34 \mathrm{e}$ & $41 d$ & $55 \mathrm{a}$ & $43 \mathrm{~cd}$ & $45 \mathrm{~cd}$ & $42 \mathrm{~cd}$ & $50 \mathrm{~b}$ & $43 \mathrm{~cd}$ & $47 \mathrm{bc}$ & $42 \mathrm{~cd}$ & \\
\hline & \multicolumn{13}{|c|}{--------------------------p------------------------ } \\
\hline $\begin{array}{l}\text { Months } \\
\text { (M) }\end{array}$ & \multicolumn{13}{|c|}{0.0001} \\
\hline $\begin{array}{l}\text { Treatments } \\
\text { (T) }\end{array}$ & \multicolumn{13}{|c|}{0.346} \\
\hline $\mathrm{MxT}$ & \multicolumn{13}{|c|}{0.999} \\
\hline C.V. $(\%)$ & \multicolumn{13}{|c|}{12.49} \\
\hline
\end{tabular}

T1: Sand (100\%); T2: Sand (20\%) + Peat (80\%); T3: Sand (90\%) + Clay soil (10\%); T4: Sand (70\%) + Sand soil (30\%).

Averages followed by uppercase letters in the column and lower case letters in the row do not differ by Tukey's test.

Results obtained for traction values on dry surfaces compared to wet surfaces for Bermuda grass were 63.1 $\mathrm{Nm}$, which is $2.4 \%$ higher than wet surfaces (MC NITT et al., 1997). The moisture value of treatment T1 (pure sand) was statistically lower than the other treatments
(Table 11). However, superficial turf traction was not reduced. Grass lawns maintained with low cutting have the highest density; however, excessively short grass weakens the aerial part and consequently reduces traction.

Table 11. Base moisture during experimentation $(n=3)$.

\begin{tabular}{|c|c|c|c|c|c|c|c|c|c|c|c|c|c|}
\hline \multirow{2}{*}{ Treatments } & \multicolumn{12}{|c|}{ Umidade da base } & \multirow[b]{2}{*}{ Average } \\
\hline & Jul & Aug & Sep & Oct & Nov & Dec & Jan & Feb & Mar & Apr & May & Jun & \\
\hline & 1 & 2 & 3 & 4 & 5 & 6 & 7 & 8 & 9 & 10 & 11 & 12 & \\
\hline T1 & 9 & 9 & 14 & 7 & 6 & 6 & 5 & 7 & 6 & 7 & 6 & 6 & $7 \mathrm{~B}$ \\
\hline $\mathbf{T} 2$ & 14 & 13 & 20 & 9 & 7 & 15 & 13 & 17 & 12 & 18 & 17 & 17 & $14 \mathrm{~A}$ \\
\hline T3 & 8 & 10 & 16 & 8 & 7 & 12 & 12 & 13 & 7 & 13 & 13 & 14 & $11 \mathrm{~A}$ \\
\hline T4 & 11 & 13 & 17 & 10 & 8 & 15 & 15 & 16 & 11 & 16 & 16 & 14 & $13 \mathrm{~A}$ \\
\hline & \multicolumn{12}{|c|}{ 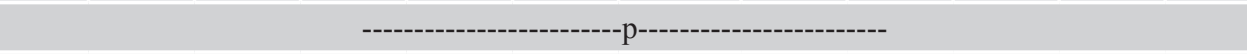 } & \\
\hline Months (M) & \multicolumn{13}{|c|}{0.0001} \\
\hline Treatments $(\mathrm{T})$ & \multicolumn{13}{|c|}{0.0001} \\
\hline $\mathrm{M} \times \mathrm{T}$ & \multicolumn{13}{|c|}{0.001} \\
\hline C.V. $(\%)$ & & & & & & & & & & & & & \\
\hline
\end{tabular}

T1: Sand (100\%); T2: Sand (20\%) + Peat (80\%); T3: Sand (90\%) + Clay soil (10\%); T4: Sand (70\%) + Sand soil (30\%).

Averages followed by uppercase letters in the column and lower case letters in the row do not differ by Tukey's test. 
Otherwise, the different mixtures in the composition of the base did not affect the playability of this experimental soccer field relative to, for example, mechanical properties and surface traction.

\section{CONCLUSIONS}

Although the treatments with peat and clay or sandy soil presented statistically higher values in some chemical characteristics of the base and grass, the quality parameters did not differ between the treatments. Thus, using pure sand is the best option for the composition of the base for natural fields covered with Bermuda grass.

\section{AUTHORS CONTRIBUTIONS}

CMAM: conception and design of the research, obtaining data, analyze and interpretation of data, statistical analysis, write and critically analyses of manuscript. MRO: conception and design of the research, obtaining data, analyze and interpretation of data, statistical analysis, write and critically analyses of manuscript. CPRPJ: analyze and interpretation of data, statistical analysis, write and critically analyses of manuscript. ART: analyze and interpretation of data, write and critically analyses of manuscript. MMPS: analyze and interpretation of data and statistical analysis of manuscript. DMF: analyze and interpretation of data, write and critically analyses of manuscript. RLLB: conception and design of the research, obtaining data, analyze and interpretation of data, write and critically analyses of manuscript and financial and obtaining funding.

\section{REFERENCES}

BAKER, K.D.; PAULSEN, M.R.; ZWEDEN, J. van. Hybrid and drying rate effects on seed corn viability. American Society of Agricultural Engineers, v.34, n.2, p.499-506, 1991. DOI: <10.13031/2013.31690>

DUBLE, R.L. Turfgrasses: their management and use in the southern zone. College Station: Texas A\&M University Press, 1996. 352p.

EMBRAPA. Sistema brasileiro de classificação de solos. Brasília: Embrapa, 2013.

FÉDÉRATION INTERNATIONALE DE FOOTBALL ASSOCIATION (FIFA). Football stadiums: technical recomendations and requirements - 4th edition. Available at: <http://www.fifa.com/mm/document/ tournament/competition/51/54/02/football_stadiums technical_recommendations_and_requirements_en_8211. pdf $>$. Accessed in: November 3rd 2010.

FERRAZ, M.V.; CENTURION, J.F., BEUTLER, A.N. Caracterização física e química de alguns substratos comerciais. Acta Scientiarum Biolgical Sciences, v.27, p.209-214, 2005.
FUCHSMAN, R.S. Potencial of peat for fuel. Minneapolis: University of Minnesota. 1974. 29p.

HOLMES, G.; BELL, M.J. A pilot study of the playing quality of football pitches. The Journal of the Sports Turf Research Institute, v.62, p.74-91, 1986.

JONES JR, J.B.; WOLF, B.; MILLS, H. A Plant analysis handbook: a practical sampling, preparation, analysis, and interpretation guide. Athens: Micro-Macro, 1991. $213 p$.

KÄMPF, A.N. Análise física de substratos para plantas. Sociedade Brasileira de Ciência do Solo, v.26, n.1, p.5-7, 2001.

KUHN, M.; HAYDEN, R. Campos de futebol para a Copa do Mundo de 2014. In: BACKES, C.; GODOY, L.J. G.; MATEUS, C.M.D.; SANTOS, A.J.M.; VILLAS BÔAS, R.L.; OLIVEIRA, M.R. Tópicos atuais em gramados III, Botucatu: Faculdade de Ciências Agronômicas, UNESP, 2012. p. 91-99.

LAMIM, A.P.B.; JORDÃO, C.P.; PEREIRA, J.L.; BELLATO, C.R. Caracterização química e física de turfa litorânea e avaliação da adsorção competitiva por cobre e zinco. Química Nova, v.24, n.1, 2001. DOI: <http://dx.doi. org/10.1590/S0100-40422001000100005>

MAGNI, S.; VOLTERRANI, M.; MIELE, S. Soccer pitches performances as affected by construction method, sand type and turfgrass mixture. Acta Horticulturae Journal, v.661, p.281-285, 2004. DOI: <10.17660/ ActaHortic.2004.661.35>

MALAVOLTA, E.; VITTI, G.C.; OLIVEIRA, S.A. Avaliação do estado nutricional das plantas: princípios e aplicações. 2. ed. Piracicaba: Potafos, 1997. 317p.

MC NITT, A.S.; MIDDOUR, R.O.; WADDINGTON, D.V. Development and evaluation of a method to measure traction on turf grass surfaces. Journal of Testing and Evaluation, v.25, n.1, p.99-107, 1997. DOI: <https://doi. org/10.1520/JTE11329J>

MCCARTY, L.B.; RODRIGUEZ, I.A.; TODD BUNNELL, B.; CLINT WALTZ, F. Fundamentals of turfgrass and agricultural chemistry. New York: Wiley, 2003. 376p. MINITAB M. Minitab Reference Manual (release 13.0). State Coll., Minitab Inc. P.A., 2000.

MORAES, M. H.; CORA, J. E.; ALMEIDA, A. B. Compactação em gramados: como avaliar e propostas para minimizar o problema. In: VILLAS BÔAS, R. L.; GODOY, L.J. G.; LIMA, C. P.; BACKES, C. Tópicos atuais em gramados. Botucatu: Faculdade de Ciências Agronômicas, UNESP, 2008. p.46-56. 
NIRSA. Campus Recreational Sports Facilities: Planning, Design and Construction Guidelines. Champaign: Human Kinetics, 2009. 296p.

PLANK, C. O.; CARROW, R. N. Plant analysis: an important tool in turf production. University of Georgia, College of Agriculture and Environmental Sciences, 2003. Available at: <http://caes2.caes.uga.edu/commodities/ turfgrass/georgiaturf/SoilTesting/analysis.html>. Accessed in: September 29 2017.

RAIJ, B.V.; ANDRADE, J.C.; CANTARELLA, H.; QUAGGIO, J.A. Análises químicas para avaliação da fertilidade de solos tropicais. Campinas: Instituto Agronômico, 2001. 285p.

SÁNCHEZ-SÁNCHEZ， J.; GARCÍA-UNANUE， J.; JIMÉNEZ-REYES, P.; GALLARDO, A.; BURILLO, P.; FELIPE, J.L.; GALLARDO, L. Influence of the mechanical properties of third-generation artificial turf systems on soccer players' physiological and physical performance and their perceptions. PLoS One, n.9, v.10, 2014. DOI: $<$ https://doi.org/10.1371/journal.pone.0111368>
SANTOS, F.R.P.; CASTILHO, R.M.M.; DUARTE, E.F. Caracterização físico-química de sete componentes de substratos recomendados para uso em floricultura. Cultura Agronômica, v.11, p.81-92, 2002.

SOCCER GRASS. Testes em gramados sintéticos. Available at: <http://www.soccergrass.com.br/testes. html>. Accessed in: September $26^{\text {th }} 2017$.

USGA. Recommendations for a method of putting green construction. 1993. Available at: http://gsrpdf.lib. msu.edu/ticpdf.py?file=/1990s/1993/930301.pdf. Accessed in: September $26^{\text {th }} 2017$.

WATSON, M.E. Plant analysis handbook: a practical sampling, preparation, analysis, and interpretation guide. Athens: Micro-Macro, 1991. 213p. 